\title{
Precipitation partitioning and related nutrient fluxes in a subtropical forest in Okinawa, Japan
}

\author{
Xiaoniu XU ${ }^{\mathrm{a}, \mathrm{b}, \mathrm{c} *}$, Qin WANG ${ }^{\mathrm{a}, \mathrm{b}}$, Eiji HIRATA ${ }^{\mathrm{b}}$ \\ a Department of Forestry, Anhui Agricultural University, Hefei, Anhui 230036, P.R. China \\ b Faculty of Agriculture, University of the Ryukyus, Nishihara, Okinawa 903-0213, Japan \\ c Present address: Field Science Center for Northern Biosphere, Hokkaido University, Nayoro, Hokkaido 096-0071, Japan
}

(Received 15 April 2004; accepted 31 August 2004)

\begin{abstract}
Precipitation partitioning into throughfall and stemflow and related hydrochemical fluxes were examined during a 3 y period from January 1998 to December 2000 in a subtropical evergreen broad-leaved forest on Okinawa Island, Japan. Monthly water samples were collected to determine the concentrations and associated fluxes of bioelements. The mean annual precipitation during the study period was $3325 \mathrm{~mm}$. Typhoons played a central role in the hydrology of the study forest with 11 typhoons contributing $29.1 \%$ of the total rainfall over the 3 y period. Throughfall and stemflow contributed $53.9 \%$ and $30.9 \%$ of the annual rainfall, respectively, implying a rainfall interception of $15.2 \%$. The very high fraction of stemflow could be due to the crown morphology of the dominant species, Castanopsis sieboldii, that has inclined branches and concave shaped leaves. Mean $\mathrm{pH}$ in the precipitation was 6.22 , and decreased significantly as the water passed through the canopy. Concentrations of total $\mathrm{N}, \mathrm{DOC}, \mathrm{K}, \mathrm{Na}, \mathrm{Ca}$, and $\mathrm{Mg}$ showed a clear pattern of enrichment in both throughfall and stemflow compared to rainfall. The proximity to the Pacific Ocean strongly influenced the nutrient fluxes via rainfall at our site as illustrated by the extremely high Na fluxes via rainfall $\left(213 \mathrm{~kg} \mathrm{Na} \mathrm{ha}^{-1} \mathrm{y}^{-1}\right)$ and throughfall plus stemflow $\left(291 \mathrm{~kg} \mathrm{Na} \mathrm{ha}^{-1} \mathrm{y}^{-1}\right)$. The mean annual nutrient inputs (in $\mathrm{kg} \mathrm{ha}^{-1}$ ) were: total N 43, P 2.6, K 76, Ca 49, Mg 30, Na 291, Al 1.8, Fe 1.0, and Mn 1.1. The input of DOC reached $361 \mathrm{~kg} \mathrm{C}^{-1} \mathrm{y}^{-1}$. The high nutrient inputs via net precipitation (throughfall plus stemflow) especially for $\mathrm{N}$ at our site is thought to reflect the frequent occurrence of sea salt-induced stress and serious herbivory by insect.
\end{abstract}

Castanopsis sieboldii / dissolved organic carbon / evergreen broad-leaved forest / nutrient cycling / stemflow / throughfall

Résumé - Partition des précipitations et flux de nutriments dans une forêt subtropicale d'Okinawa au Japon. La partition des précipitations entre eau arrivant directement au sol et écoulement le long des troncs et flux hydrochimiques liés a été étudié pendant 3 ans de janvier 1998 à décembre 2000 dans une forêt feuillue à feuilles persistantes de l'île d'Okinawa au Japon. Mensuellement des échantillons d'eau étaient collectés pour déterminer les concentrations et les flux des bioéléments. Les précipitations annuelles moyennes pendant la période étudiée ont atteint $3325 \mathrm{~mm}$. Les typhons jouent un rôle central dans l'hydrologie de la forêt étudiée avec 11 typhons contribuant à $29,1 \%$ des précipitations totales pour les 3 ans de la période d'étude. L'eau arrivant directement au sol et l'écoulement le long des troncs représentent respectivement 53,9\% et 30,9\% des précipitations incidentes annuelles, impliquant une interception des précipitations de 15,2\%. La part importante de l'écoulement le long des troncs pourrait être dû à la morphologie des couronnes de l'espèce dominante Castanopsis sieboldii qui a des branches inclinées et des feuilles de formes concaves. Le pH des précipitations incidentes était de 6,22, il baissait significativement avec la traversée de l'eau à travers les couronnes. Les concentrations totales de N, DOC (carbone organique dissous), K, Na, Ca et Mg montrent un modèle évident d'enrichissement au niveau de l'eau traversant directement les couronnes et de l'écoulement le long des troncs comparativement aux précipitations incidentes. La proximité de l'Océan Pacifique influence fortement lees flux de nutriments dans le site étudié comme le montre les flux élevés de $\mathrm{Na}$ apportés par les précipitations incidentes $\left(213 \mathrm{~kg} \mathrm{Na} \mathrm{ha}^{-1} \mathrm{an}^{-1}\right)$ et l'eau arrivant directement au sol et l'écoulement le long des troncs $\left(291 \mathrm{~kg} \mathrm{Na} \mathrm{ha}^{-1} \mathrm{an}^{-1}\right.$ ). La moyenne annuelle des apports de nutriments était de (en $\mathrm{kg} \mathrm{ha}$ ): $\mathrm{N}$ total 43, P 2,6, K 76, Ca 49, Mg 30, $\mathrm{Na} 291, \mathrm{Al} 1,8, \mathrm{Fe} 1,0$ et Mn 1,1. L'apport de DOC a atteint $361 \mathrm{~kg}$ de carbone par hectare et par an. L'apport élevé de nutriments par l'ensemble des précipitations arrivant au sol (eau traversant directement plus écoulement le long des troncs) particulièrement en ce qui concerne $\mathrm{N}$ peut être le reflet des stress induits par l'eau salée et les insectes herbivores.

Castanopsis sieboldii / carbone organique dissous / forêt feuillue à feuilles persistantes / cycle des nutriments / écoulement le long des troncs / eau arrivant directement au sol

\section{INTRODUCTION}

Nutrient inputs and outputs are directly related to the magnitude of the fluxes of water moving into and out of ecosystems, resulting in an additional transfer of nutrients with different components $[15,35]$. The chemistry of bulk precipitation can be changed considerably after passing through forest canopy to the ground [35]. Nutrient concentrations in throughfall and

\footnotetext{
* Corresponding author: xiaoxu@fsc.hokudai.ac.jp; xiaoniu61@yahoo.co.jp
} 
stemflow are modified mainly through the processes of washoff of materials deposited during the previous period without rain, and by leaching of nutrient from plants, and absorption of ions from the rain $[34,36]$. The actual nutrient balances depend on forest type, rainfall excess and soil types and may reflect different patterns of behavior in nutrients in different ecosystems $[5,8,24,30]$.

There is considerable information on biogeochemical fluxes for temperate forests in Japan [20] but much less is known about this aspect for the subtropical forests on Okinawa Island, southwestern Japan. Overall, the understanding of biogeochemical cycling in tropical and subtropical forests is still relatively poor compared with temperate forests $[6,42]$.

Okinawa Island, especially in its northern part, is mainly covered by evergreen broad-leaved native forest dominated by Castanopsis sieboldii Hatusima ex Yamazaki \& Mashiba (Fagaceae) and Schima wallichii Kort. (Theaceae). This forest is considered to have great structural complexity, as well as considerable functional and biological diversity $[19,45]$. Therefore, sustainable management for this forest has been identified as a priority for research [19]. The main objective of this study is to determine: (1) precipitation and redistribution processes; (2) changes in precipitation chemistry during the transfer of solutions within the canopy; and (3) annual nutrient fluxes by rainfall. This study provides basic information on the behavior of the water balance and nutrient cycling in the subtropical forest on Okinawa Island.

\section{MATERIALS AND METHODS}

\subsection{Study site}

The study site is located in the Yona Experimental Forest of the University of the Ryukyus ( $26^{\circ} 45^{\prime} \mathrm{N}$ and $128^{\circ} 10^{\prime} \mathrm{E}$; Fig. 1). The experimental plot situated in hilly terrain on an upper slope (24) facing $\mathrm{N} 65^{\circ} \mathrm{W}$

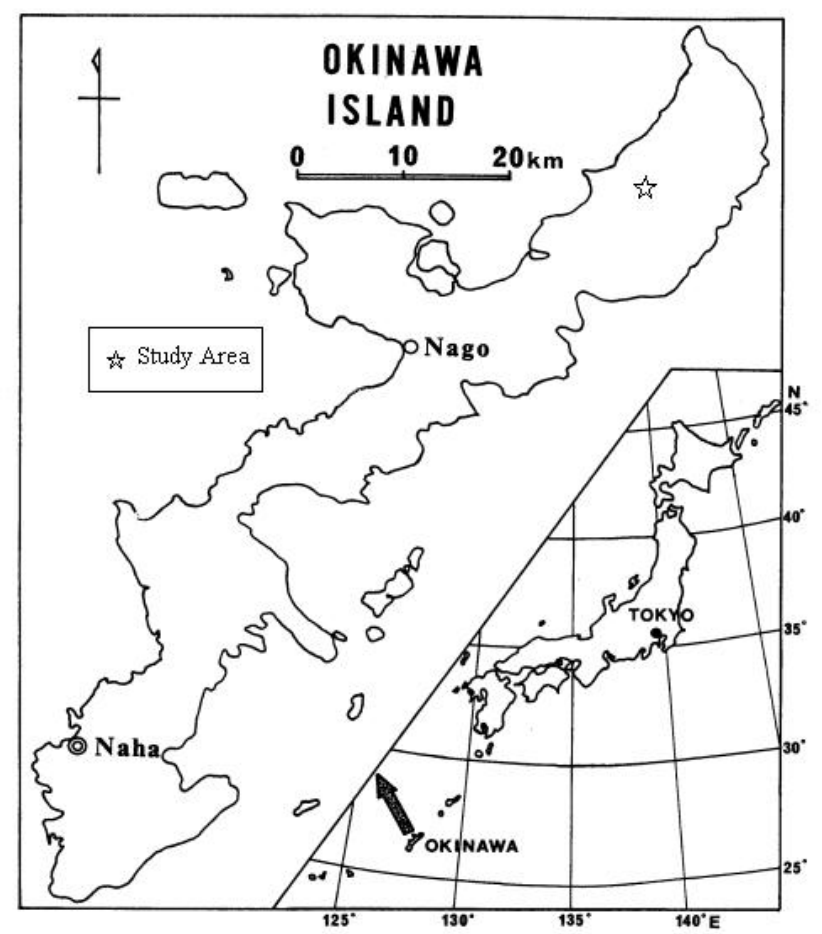

Figure 1. Location of the study site.

at an altitude of $260 \mathrm{~m}$ asl. The highest peak, Mt. Yonaha, is $498 \mathrm{~m}$ asl. Trees with $D B H$ greater than $3.0 \mathrm{~cm}$ were found at a density of $6625 \mathrm{stems} \mathrm{ha}^{-1}$. The total basal area was $45 \mathrm{~m}^{2} \mathrm{ha}^{-1}$, of which the canopy dominants, C. sieboldii and S. wallichii, contributed $78 \%$ of the total (Tab. I).

The study area has a maritime subtropical climate with abundant rainfall. Long-term (1963-1996) mean annual precipitation in the area

Table I. Basic characteristics of the sampling stand $(D B H \geq 3.0 \mathrm{~cm})$.

\begin{tabular}{|c|c|c|c|c|c|c|c|c|}
\hline \multirow{2}{*}{ Species composition } & \multicolumn{2}{|c|}{$D B H(\mathrm{~cm})$} & \multicolumn{2}{|c|}{ Height (m) } & \multicolumn{2}{|c|}{ Density } & \multicolumn{2}{|c|}{ Basal area } \\
\hline & Mean & Range & Mean & Range & Stems & $\%$ & $\mathrm{~cm}^{2}$ & $\%$ \\
\hline Castanopsis sieboldii & 11.3 & $4.2-29.7$ & 9.2 & $7.5-11.5$ & 225 & 37.4 & 25083 & 59.9 \\
\hline Schima wallichii & 14.0 & $9.8-32.2$ & 10.1 & $8.5-12.5$ & 41 & 6.8 & 7355 & 17.6 \\
\hline Daphniphyllum glaucescens & 7.8 & $3.1-10.6$ & 7.3 & $3.8-8.5$ & 38 & 6.3 & 2259 & 5.4 \\
\hline Rapanea neriifolia & 4.4 & $3.0-6.7$ & 5.2 & $3.5-6.8$ & 68 & 11.3 & 1296 & 3.1 \\
\hline Elaeocarpus japonicus & 6.2 & $3.6-8.6$ & 6.5 & $5.3-8.2$ & 32 & 5.3 & 1179 & 2.8 \\
\hline Cinnamoтum doederleinii & 5.5 & $4.2-7.7$ & 7.2 & $5.6-8.3$ & 41 & 6.8 & 1098 & 2.6 \\
\hline Ilex liukiuensis & 4.9 & $3.9-9.1$ & 6.2 & $4.4-7.5$ & 41 & 6.8 & 909 & 2.2 \\
\hline Rhaphiolepis indica & 7.4 & $6.7-15.7$ & 7.0 & $5.6-8.7$ & 11 & 1.8 & 558 & 1.3 \\
\hline Syzygium buxifolium & 4.5 & $3.1-6.5$ & 5.2 & $3.8-7.6$ & 29 & 4.8 & 549 & 1.3 \\
\hline Myrica rubra & 13.6 & $11.6-15.9$ & 8.0 & $7.8-8.6$ & 5 & 0.8 & 382 & 0.9 \\
\hline Persea thunbergii & 9.1 & $8.1-12.3$ & 10.0 & $9.5-10.8$ & 5 & 0.8 & 206 & 0.5 \\
\hline Others (15 species) & 4.2 & $3.0-8.7$ & 5.3 & $3.3-8.2$ & 66 & 11.0 & 1017 & 2.4 \\
\hline Total & & & & & 602 & 100 & 41891 & 100 \\
\hline
\end{tabular}


Table II. Species composition of the subplot for stemflow measurement.

\begin{tabular}{|c|c|c|c|c|c|c|c|c|}
\hline \multirow{2}{*}{ Species composition } & \multicolumn{2}{|c|}{$D B H(\mathrm{~cm})$} & \multicolumn{2}{|c|}{ Height (m) } & \multicolumn{2}{|c|}{ Density } & \multicolumn{2}{|c|}{ Basal area } \\
\hline & Mean & Range & Mean & Range & Stems & $\%$ & $\mathrm{~cm}^{2}$ & $\%$ \\
\hline Castanopsis sieboldii & 14.1 & $2.8-24.9$ & 9.3 & $4.3-11.0$ & 7 & 25.0 & 1302 & 62.8 \\
\hline Schima wallichii & 18.3 & $17.2-19.4$ & 11.3 & $11.0-11.5$ & 2 & 7.1 & 528 & 25.5 \\
\hline Daphniphyllum glaucescens & 6.2 & $3.8-8.6$ & 6.8 & $5.5-8.0$ & 2 & 7.1 & 69 & 3.3 \\
\hline Rapanea neriifolia & 3.9 & $2.1-6.0$ & 4.8 & $3.0-7.0$ & 6 & 21.4 & 42 & 2.0 \\
\hline Symplocos prunifolia & 6.1 & & 9.0 & & 1 & 3.6 & 29 & 1.4 \\
\hline Ilex liukiuensis & 3.8 & $2.8-4.8$ & 6.4 & $5.3-7.5$ & 2 & 7.1 & 24 & 1.2 \\
\hline Cinnamomum doederleinii & 5.5 & & 6.0 & & 1 & 3.6 & 24 & 1.1 \\
\hline Rhaphiolepis indica & 4.8 & & 5.0 & & 1 & 3.6 & 18 & 0.9 \\
\hline Syzygium buxifolium & 4.7 & & 3.8 & & 2 & 7.1 & 17 & 0.8 \\
\hline Diplospora dubia & 3.6 & & 3.3 & & 2 & 7.1 & 10 & 0.5 \\
\hline Randia canthioides & 2.6 & & 3.5 & & 1 & 3.6 & 5.2 & 0.2 \\
\hline Microtropis japonica & 2.3 & & 3.0 & & 1 & 3.6 & 4.2 & 0.2 \\
\hline Total & & & & & 28 & 100 & 2072 & 100 \\
\hline
\end{tabular}

is $2680 \mathrm{~mm} \mathrm{y}^{-1}$, with an annual maximum of $3982 \mathrm{~mm} \mathrm{y}^{-1}$ in 1969 and an annual minimum of $1905 \mathrm{~mm} \mathrm{y}^{-1}$ in 1977. Mean annual pan evaporation is about $1600 \mathrm{~mm} \mathrm{y}^{-1}$. The annual mean temperature is $21.6^{\circ} \mathrm{C}$, with January and July being the coldest and hottest months, with temperatures averaging $5.4{ }^{\circ} \mathrm{C}$ and $34.5^{\circ} \mathrm{C}$, respectively (Yona Experimental Forest, University of the Ryukyus). Typhoons occur frequently between July and October, bringing high rainfall and strong winds to the island.

The soil of the study site has a clay loam texture, and has developed from Palaeozoic clay-slate, with acid characteristics. Soil pH is 4.1. Concentrations of total organic $\mathrm{C}$ and total $\mathrm{N}$ are 72.5 and $3.6 \mathrm{~g} \mathrm{~kg}^{-1}$. Exchangeable cations are: $\mathrm{K}^{+} 0.61, \mathrm{Ca}^{2+} 3.01, \mathrm{Mg}^{2+} 1.44 \mathrm{cmol}(+) \mathrm{kg}^{-1}$, respectively, in the top $10 \mathrm{~cm}$ mineral horizon [46]. This soil type corresponds to a Typic Paleudults according to the USDA classification [40].

\subsection{Hydrological measurements}

At the study site, a representative plot of $30 \mathrm{~m} \times 30 \mathrm{~m}$ was delimited. Rainfall, throughfall and stemflow solutions were collected once or twice a month from January 1998 to December 2000. Rainfall was collected in two rain gauges situated $1.5 \mathrm{~m}$ above the ground in a clearing (about $20 \mathrm{~m} \times 20 \mathrm{~m}$ ) on a flat ridge adjacent (about $50 \mathrm{~m}$ distant) to the experimental plot. Throughfall was collected with four PVC gutters (each with a collecting area of $0.4 \mathrm{~m}^{2}$, i.e. $20 \mathrm{~cm} \times 200 \mathrm{~cm}$ ) situated at a height of $1.0 \mathrm{~m}$ with the flow passing into self-empty, tipping bucket with one empty of $500 \mathrm{~mL}$, and then the solution was channelled into polyethylene containers of $20 \mathrm{~L}$. Stemflow was collected from all trees $(D B H \geq 2.0 \mathrm{~cm}$; Tab. II) in a $6 \mathrm{~m} \times 6 \mathrm{~m}$ subplot with polyurethane foam collars that were sealed at the trunk with ethylene compound at a height of about $1.2 \mathrm{~m}$ above the soil. Stemflow was channelled from the collars through polyethylene tube into three PVC pipes of $4 \mathrm{~m}$ long. After passing through the self-empty, tipping bucket with one empty of $500 \mathrm{~mL}$, then the stemflow solution was collected into $20 \mathrm{~L}$ containers. Throughfall and stemflow collectors were provided with filters (mesh size $1 \mathrm{~mm}$ ) to prevent contamination with litter and other biological material. The volumes of throughfall and stemflow were measured by an automatic recorder setting at one-hour interval (KADEC-PLS data logger; KONA System Co. Ltd, Tokyo).

After each collection of solution samples, the containers were thoroughly washed. Because of logistical considerations and limited resources, sample collections were only conducted monthly or twice a month over the 3-y period.

\subsection{Chemical analysis}

All samples collected were transported to the laboratory as soon as possible and preserved at $5{ }^{\circ} \mathrm{C}$. The $\mathrm{pH}$ was measured using a glass electrode. Unfiltered subsamples $(50 \mathrm{~mL})$ were used to determine dissolved organic carbon (DOC). Subsamples were filtered with $0.65 \mu \mathrm{m}$ Whatman filter paper. The concentrations of $\mathrm{P}, \mathrm{K}, \mathrm{Ca}, \mathrm{Mg}, \mathrm{Al}, \mathrm{Na}, \mathrm{Fe}$, and $\mathrm{Mn}$ were determined by inductively coupled plasma spectrometer (Shimadzu, ICPS-2000). The samples for total N determination were digested in a mixture of perchloric and sulphuric acids $(100 \mathrm{~mL}$ samples of water in $10 \mathrm{~mL}$ mixed acids). Then $\mathrm{NH}_{4}{ }^{+}-\mathrm{N}$ concentrations were analyzed using the Nessler method and $\mathrm{NO}_{3}^{-}-\mathrm{N}$ concentrations using the phenoldisulphonic method [16]. Finally, DOC was determined by oxidation with permanganate by the method of Barlett \& Ross [2].

\subsection{Data analysis}

Based on the samples analyzed for each hydrological component, elemental concentrations between different components were compared statistically using one-way analysis of variance, followed by multiple comparisons to detect whether significant differences occurred among components. The statistical analyses were performed using the Statistica package [41]. Differences were considered statistically significant at $P \leq 0.05$. The element fluxes were calculated by multiplying the amount of water with the corresponding concentrations obtained in a specific month.

\section{RESULTS}

\subsection{Water fluxes}

During the study period from January 1998 to December 2000 , the precipitation recorded in the ridge clearing was $4318 \mathrm{~mm}$ in 1998, $2231 \mathrm{~mm}$ in 1999, and $3424 \mathrm{~mm}$ in 2000 . The proportion of the rain which reached the forest floor as throughfall and 


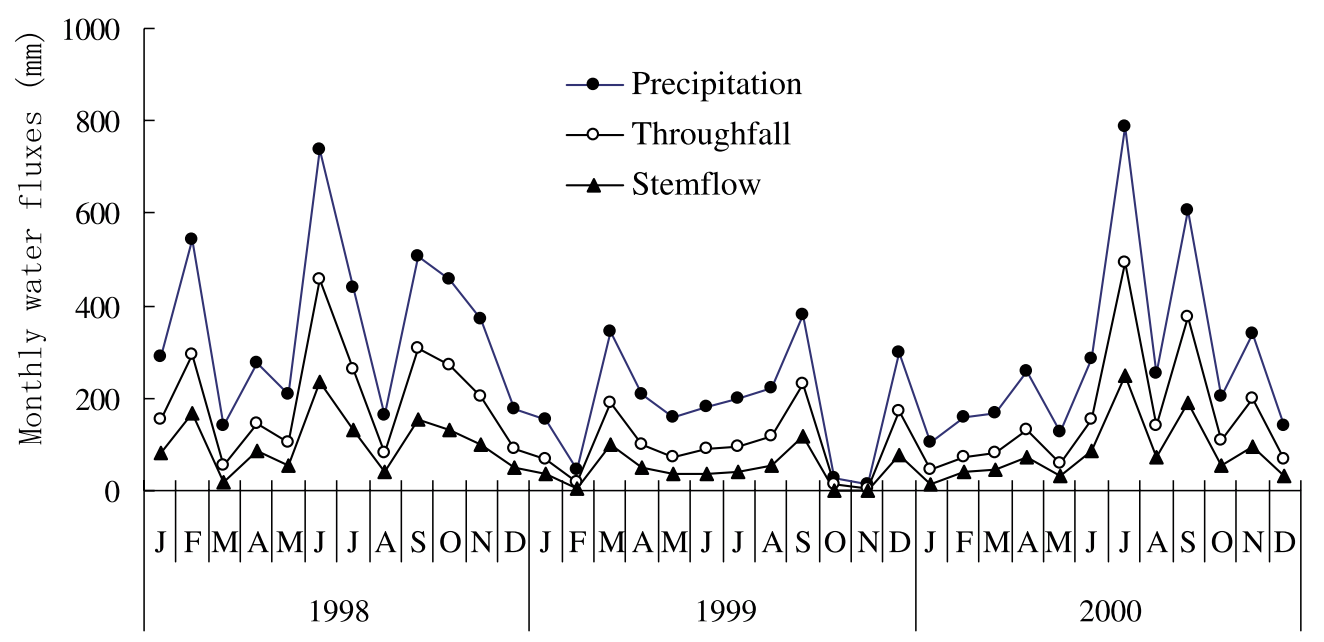

Time (month and year)

Figure 2. Monthly variation of precipitation, throughfall and stemflow in the subtropical forest on Okinawa Island, Japan between 1998 and 2000.

Table III. Annual water fluxes (mm; Jan. 1998-Dec. 2000) in the different levels in the subtropical forest on Okinawa Island, Japan.

\begin{tabular}{|c|c|c|c|c|c|}
\hline \multicolumn{2}{|l|}{ Year } & 1998 & 1999 & 2000 & Mean $^{\#}$ \\
\hline \multicolumn{2}{|c|}{ Incident precipitation $(I P)$} & 4320 & 2231 & 3424 & $3325(1048)$ \\
\hline \multirow[t]{2}{*}{ Throughfall $(T F)$} & Amount & 2383 & 1176 & 1822 & $1794(604)$ \\
\hline & Percentage & 55.2 & 52.7 & 53.2 & 53.9 \\
\hline \multirow[t]{2}{*}{ Stemflow $(S F)$} & Amount & 1386 & 615 & 1085 & $1029(389)$ \\
\hline & Percentage & 32.1 & 27.6 & 31.7 & 30.9 \\
\hline \multirow[t]{2}{*}{$T F+S F$} & Amount & 3769 & 1791 & 2907 & $2822(992)$ \\
\hline & Percentage & 87.2 & 80.3 & 84.9 & 84.8 \\
\hline \multirow[t]{2}{*}{ Interception (I) } & Amount & 551 & 440 & 517 & $502(57)$ \\
\hline & Percentage & 12.8 & 19.7 & 15.1 & 15.2 \\
\hline
\end{tabular}

\# Values in the parentheses are standard deviations.

stemflow averaged $84.8 \%$ over the 3 y study period, of which throughfall contributed $53.9 \%$ and stemflow $30.9 \%$, implying an average rainfall interception of $15.2 \%$ (Tab. III).

The monthly variation of precipitation during the study period is given in Figure 2. The importance of intensive storms occurring from June to September is seen in the contribution of typhoons to total annual precipitation. Two typhoons occurred in 1998 and contributed $800 \mathrm{~mm}$ of rainfall, representing $18.5 \%$ of the annual precipitation that year; four typhoons in 1999 contributed $590 \mathrm{~mm}$ of rainfall, representing $26.4 \%$; and five typhoons in 2000 contributed $1450 \mathrm{~mm}$ of rainfall, representing $42.3 \%$ of the annual precipitation.

\subsection{Nutrient concentrations}

The mean $\mathrm{pH}$ of the rainwater was 6.2 ranging from 5.4 to 6.8 , and decreased as it moved through the forest canopy to the forest floor. Throughfall and stemflow were slightly more acid (mean values 5.9 and 5.8, respectively) compared to rainfall $(P<0.05$; Tab. IV $)$.
Volume-weighted mean element concentrations of precipitation, throughfall, and stemflow are summarized on Table IV. The most abundant element in the precipitation was $\mathrm{Na}$, followed by $\mathrm{K}$ and $\mathrm{Ca}$. All elements measured were enriched while passing through the forest canopy. Stemflow was usually more concentrated than throughfall, though the increase was strictly significant for $\mathrm{K}, \mathrm{Na}, \mathrm{Mg}, \mathrm{Mn}$, and total $\mathrm{N}$. Concentrations of $\mathrm{Na}, \mathrm{K}, \mathrm{Ca}, \mathrm{Mg}$, total $\mathrm{N}$, and DOC increased significantly in the sequence from rainfall to throughfall and to stemflow. The concentration of DOC in the precipitation averaged $4.3 \mathrm{mg} \mathrm{L}^{-1}$ while in throughfall and stemflow the corresponding values were 11.5 and $15.5 \mathrm{mg} \mathrm{L}^{-1}$, respectively (Tab. IV).

Significant seasonal changes in element concentration were detected for both throughfall and stemflow. Concentrations of $\mathrm{Na}, \mathrm{K}, \mathrm{Ca}$, and $\mathrm{Mg}$ were greater in the months with low rainfall than in the months with high rainfall. However, Na concentrations were extremely high in the typhoon season despite the high rainfall. On opposite, concentrations of $\mathrm{Al}, \mathrm{Fe}, \mathrm{Mn}, \mathrm{K}, \mathrm{Ca}$, and $\mathrm{Mg}$ in the precipitation differed little throughout the year. DOC in the precipitation varied slightly while $\mathrm{pH}$ varied irregularly with relatively lower values during October to January. 
Table IV. Mean concentrations of nutrients $\left(\mathrm{mg} \mathrm{L}^{-1}\right)$ with SD $(n=45)$ in the different levels in the subtropical forest on Okinawa Island, Japan. Same letters indicate samples that are not significantly different $(P \leq 0.05)$ within a column.

\begin{tabular}{|c|c|c|c|c|c|c|c|c|c|c|c|}
\hline & $\mathrm{pH}$ & Total N & $\mathrm{P}$ & $\mathrm{K}$ & $\mathrm{Ca}$ & $\mathrm{Mg}$ & $\mathrm{Na}$ & $\mathrm{Al}$ & $\mathrm{Fe}$ & $\mathrm{Mn}$ & DOC \\
\hline$I P$ & $6.2 \mathrm{a}$ & $0.66 \mathrm{a}$ & $0.072 \mathrm{a}$ & $0.59 \mathrm{a}$ & $0.90 \mathrm{a}$ & $0.49 \mathrm{a}$ & $6.57 \mathrm{a}$ & $0.03 \mathrm{a}$ & $0.03 \mathrm{a}$ & $0.03 \mathrm{a}$ & $4.3 \mathrm{a}$ \\
\hline S.D. & 0.36 & 0.226 & 0.03 & 0.25 & 0.32 & 0.23 & 3.90 & 0.01 & 0.01 & 0.01 & 1.6 \\
\hline$T F$ & $5.9 \mathrm{~b}$ & $1.31 \mathrm{~b}$ & $0.092 b$ & $2.34 \mathrm{~b}$ & $1.52 \mathrm{a}$ & $0.93 b$ & $9.88 \mathrm{a}$ & $0.07 \mathrm{~b}$ & $0.04 \mathrm{a}$ & $0.04 \mathrm{ab}$ & $11.5 \mathrm{~b}$ \\
\hline S.D. & 0.17 & 0.41 & 0.04 & 0.770 & 0.640 & 0.430 & 5.01 & 0.04 & 0.02 & 0.02 & 4.8 \\
\hline$S F$ & $5.8 \mathrm{~b}$ & $2.45 \mathrm{c}$ & $0.088 \mathrm{ab}$ & $4.55 c$ & $2.72 b$ & $1.73 \mathrm{c}$ & $14.91 \mathrm{~b}$ & $0.08 \mathrm{~b}$ & $0.05 b$ & $0.06 \mathrm{~b}$ & $15.5 \mathrm{c}$ \\
\hline S.D. & 0.19 & 1.03 & 0.04 & 1.98 & 1.34 & 0.75 & 8.16 & 0.04 & 0.02 & 0.02 & 6.3 \\
\hline
\end{tabular}

Table V. Mean annual nutrient fluxes $\left(\mathrm{kg} \mathrm{ha}^{-1} \mathrm{y}^{-1}\right)$ in the different precipitation components in the subtropical forest on Okinawa Island, Japan during a period of 3 years (Jan. 1998-Dec. 2000).

\begin{tabular}{lcccccccccc}
\hline & Total N & $\mathrm{P}$ & $\mathrm{K}$ & $\mathrm{Ca}$ & $\mathrm{Mg}$ & $\mathrm{Na}$ & $\mathrm{Al}$ & $\mathrm{Fe}$ & $\mathrm{Mn}$ & $\mathrm{DOC}$ \\
\hline$I P$ & 21.9 & 2.40 & 19.7 & 29.8 & 16.2 & 218 & 1.08 & 0.96 & 1.00 & 139 \\
$T F$ & 22.4 & 1.64 & 41.2 & 27.3 & 16.7 & 157 & 1.28 & 0.66 & 0.74 & 204 \\
$S F$ & 20.8 & 0.91 & 34.3 & 21.3 & 13.1 & 134 & 0.58 & 0.36 & 0.38 & 158 \\
$T F+S F$ & 43.2 & 2.55 & 75.5 & 48.6 & 29.7 & 291 & 1.85 & 1.01 & 1.12 & 362 \\
$(T F+S F) / I P$ & 1.97 & 1.06 & 3.83 & 1.63 & 1.84 & 1.33 & 1.72 & 1.06 & 1.12 & 2.60 \\
\hline
\end{tabular}

\subsection{Nutrient fluxes}

The annual nutrient fluxes via precipitation, throughfall, and stemflow are shown in Table V. The annual total $\mathrm{N}$ flux in bulk precipitation was $21.9 \mathrm{~kg} \mathrm{ha}^{-1}$. Whereas the total $\mathrm{N}$ transferred to the forest floor in throughfall plus stemflow ranged from 33.9 to $44.2 \mathrm{~kg} \mathrm{ha}^{-1} \mathrm{y}^{-1}$ over the 3 y period, suggesting considerable transfer of $\mathrm{N}$ from the canopy.

The fluxes of $\mathrm{P}, \mathrm{Fe}$, and Mn differed only slightly between precipitation and throughfall plus stemflow. The annual fluxes of $\mathrm{K}, \mathrm{Ca}$, and $\mathrm{Mg}$ in throughfall plus stemflow averaged $75.5 \mathrm{~kg} \mathrm{ha}^{-1}, 48.6 \mathrm{~kg} \mathrm{ha}^{-1}$ and $29.8 \mathrm{~kg} \mathrm{ha}^{-1}$, respectively, and were greater than those in precipitation (K $283 \%, \mathrm{Ca} 62.8 \%$ and $\mathrm{Mg}$ 83.8\%, respectively).

Of all elements measured, the Na fluxes were the highest with 218 and $291 \mathrm{~kg} \mathrm{ha}^{-1} \mathrm{y}^{-1}$ in rainfall and throughfall plus stemflow, respectively. In addition, element fluxes were higher in the wet season than in the dry season due to the much larger amount of rainfall. During the 3 y studied, the annual flux of DOC averaged $362 \mathrm{~kg} \mathrm{ha}^{-1} \mathrm{y}^{-1}$ in throughfall plus stemflow (Tab. V), in which the total net below-canopy fluxes contributed $61.5 \%$.

\section{DISCUSSION}

\subsection{Precipitation partitioning}

Rainfall data from the present study indicated that the precipitation differed significantly between consecutive years. The total precipitation in 1998 reached $4318 \mathrm{~mm}$, which was about twice as high as in 1999 (Tab. III). However, the distribution (in percentage) of precipitation among throughfall, stemflow, and interception by vegetation varied little over $3 \mathrm{y}$.
This may be due to the relative great intensity of the rainfall and tree shape in the study area. Throughfall made up an average of $53.9 \%$ of the annual precipitation whereas stemflow was $30.9 \%$, a very high value. Hölscher et al. [17] reported that stemflow represented $23 \%$ and $41 \%$ of the annual precipitation, respectively, in a diverse and a mono-specific young secondary forests in Amazon that were rich in banana-palm like species. Similarly, Lloyd and Marqués [28] and Schroth et al. [39] identified a palm species with high stemflow. Whilst in a young subtropical Costa Rican forest, Raich [37] also measured a high stemflow rate on trees with banana-palm like leaves. The reason for the high value of stemflow at our site could be related to the crown morphology of the dominant species, C. sieboldii, which has inclined branches and concave shaped leaves. In addition, wind speed [23] and very high rainfall [43] can also affect the stemflow rate. On Okinawa, windstorms, particularly typhoon events, are very frequent and this may be an important cause of the high fraction of stemflow. The proportion of rainfall interception (15.2\%) in this study is at the lowest of the widely reported range of 15-30\% for many broad-leaved evergreen forests $[9,12,18]$ but is higher than that reported for a subtropical rain forest in Taiwan [26]. Fujimoto [13] reported that interception represented $20.2-48.2 \%$ of annual precipitation for temperate evergreen broad-leaved forests in Kochi, Japan. Such differences may result from the differences in forest structure [9, 21], temperature (governing wet canopy evaporation rate), and intensity of rainfalls $[23,26]$, as well as the sampling design $[14,28]$.

Lloyd and Marqués [28] had ever pointed out that using more gauges and moving them randomly over time could increase the throughfall catch and thus values of interception loss resulting lowers and were realistic. In the present study, the throughfall collectors were fixed over $3 \mathrm{y}$ without moving those over time. In addition, only four collectors were used although the collecting 
Table VI. Comparison of annual nutrient fluxes $\left(\mathrm{kg} \mathrm{ha}^{-1} \mathrm{y}^{-1}\right)$ via throughfall and stemflow in some tropical and subtropical forests.

\begin{tabular}{lccccccccc}
\hline Forest type and site & $I P(\mathrm{~mm})$ & $T F+S F(\mathrm{~mm})$ & Total N & $\mathrm{P}$ & $\mathrm{K}$ & $\mathrm{Ca}$ & $\mathrm{Mg}$ & $\mathrm{Na}$ & Source \\
\hline Tropical rain forest & & & & & & & & & \\
$\quad$ New Guinea & 3800 & 2585 & 36 & 3.0 & 78 & 23 & 12 & - & Edwards, 1982 [12] \\
Ivory Coast & 1800 & 1640 & 81 & 9.8 & 175 & 47 & 49 & - & Bernhard-Renversat, 1975 [3] \\
Puerto Rico & 5000 & 6800 & 69 & 0.24 & 77 & 109 & 91 & 692 & Asbury et al., 1994 [1] \\
$\quad$ Yunnan, China & 2165 & 1925 & 13 & 1.5 & 34 & 16 & 10 & 2.2 & Liu et al., 2003 [27] \\
Subtropical forest & & & & & & & & & \\
Okinawa, Japan & 3324 & 2822 & 43 & 2.6 & 76 & 49 & 30 & 291 & This study \\
Taiwan & 4104 & 3816 & 34 & - & 59 & 49 & 16 & 51 & Lin et al., 2000 [26] \\
Fujian, China & 2679 & - & 34 & 1.8 & 13 & 23 & 2.1 & 6.7 & Li, 1998 [25] \\
Coastal Australia & - & - & 95 & 0.16 & 12 & 17 & 13 & 94 & Westman, 1978 [44] \\
\hline
\end{tabular}

area was rather large (a total of $1.6 \mathrm{~m}^{2}$ ). This sampling design could be responsible for the low throughfall.

\subsection{Nutrient concentration and fluxes in precipitation components}

There was a definite difference in nutrient concentration among precipitation, throughfall, and stemflow (Tab. III). The order of the nutrient concentrations in this study was always: stemflow $>$ throughfall $>$ precipitation, throughout the $3 \mathrm{y}$ period. The differences were large for $\mathrm{K}, \mathrm{Na}, \mathrm{N}, \mathrm{Ca}$, and $\mathrm{Mg}$, and small for $\mathrm{P}, \mathrm{Fe}$ and $\mathrm{Mn}$. The results are similar to those of many other studies [7, 11, 26, 27]. It is generally assumed that the wash-off of aerosol impact on the canopy (including branches and trunks) and leaching from the leaves are the two major sources of the extra nutrients in throughfall and stemflow [11]. Some studies of dry deposition have indicated that impacted terrestrial aerosols are not negligibly small as a component of the chemicals in throughfall and stemflow [11, 29, 33]. In this study, only the inputs by means of bulk precipitation have been considered, which includes any aerosols (including sea spray) washed from the atmosphere during rainfall as well as dry deposition onto the collector funnel [4]. Okinawa is a small island without any large industrial plants and far from the Asian Continent. Particularly, in summer and autumn (June to October), the source of precipitation was exclusively from the Pacific Ocean, with little influence by air masses coming from the continent. Therefore, the impaction of aerosols of terrestrial origin is not important in this subtropical forest.

The abundance of $\mathrm{Na}$ in precipitation, throughfall, and stemflow at the study site indicates the strong oceanic influence. Because Okinawa is an island, oceanic influences on the precipitation chemistry are common around the island [22]. In addition, typhoons are frequent. Typhoon events can bring a large amount of rainfall with high concentrations of $\mathrm{Na}$ and $\mathrm{Cl}$ to the island $[13,22,43]$. Comparing the chemistry of precipitation and runoff at 47 forested sites in the whole of Japan, Iwatsubo et al. [20] found that concentrations of $\mathrm{Cl}$ and $\mathrm{Na}$ in rainfall and runoff were significantly and negatively correlated to distance from the sea. Those results indicate the importance of typhoon events in the hydrology and biogeochemistry of the forests in Okinawa.
The precipitation was not acidic (mean $\mathrm{pH}=6.2, n=45$ ). Similar $\mathrm{pH}$ value has been reported for a tropical montane forest without pollution in south-western China [27]. The $\mathrm{pH}$ decreased significantly as the water passed through the canopy in the present study. A similar decline in $\mathrm{pH}$ with passage through the different levels of vegetation has been reported for other forests [26, 27, 34], and has been attributed to the corresponding increase in organic acids [34]. In the present study, DOC concentrations in throughfall and stemflow were, respectively, 2.7 and 3.6 times as high as that in the precipitation.

The rank by enrichment (in percentage) of bioelements in throughfall and stemflow in the present study was $\mathrm{K}>\mathrm{Mg}>$ $\mathrm{Ca}>\mathrm{Na}$ for cations, which is similar to those for other subtropical and tropical forests $[3,12,25,26]$. Enrichments in $\mathrm{K}$ and $\mathrm{Mg}$ in throughfall and stemflow came mainly from foliage leaching [31]. Ca was mainly from dry deposition and was almost imperceptible from canopy exchange [32]. Na came almost from rainfall, with appreciable values of wash-off and marine origin $[13,35]$. In addition, our site is characterized by an extremely large quantity of $\mathrm{Na}$ flux $\left(291 \mathrm{~kg} \mathrm{ha}^{-1} \mathrm{y}^{-1}\right)$ in throughfall and stemflow (Tab. VI). The annual inputs of nutrients to the Okinawan subtropical forest are intermediate between the low inputs to the Ailao Montane forest in southwestern China [27] and the very high inputs to the Valley forest in Ivory Coast which experiences a significant dry season with dry deposition [3]. Table VI shows different references dealing with annual nutrient fluxes, although the data are limited, it is clear that throughfall plus stemflow are generally a relatively minor vector for $\mathrm{P}$ transfer in most tropical and non-tropical forests [42]; however it is the major pathway for $\mathrm{K}$ and Na transfers. $\mathrm{N}$ flux is considerably high in some forests. Our site has a total $\mathrm{N}$ flux (including DON and DIN) of $43 \mathrm{~kg} \mathrm{ha}^{-1} \mathrm{y}^{-1}$ in throughfall plus stemflow. It demonstrates that the throughfall plus stemflow is an important pathway for $\mathrm{N}$ transfer in the Okinawan subtropical forest, although litterfall is the major pathway for nutrient transfer [38].

Differences in nutrient fluxes between rainfall and net precipitation (throughfall + stemflow) are indicative of the magnitude of canopy leaching [35]. At our site, canopy leaching of bioelements was relatively high compared with the tropical montane forests in China [25, 27], but lower than that in tropical forests in Papua New Guinea [12] and the Ivory Coast [3]. 
Generally, low canopy leaching is probably attributable to physiological characteristics of tree species [10], low concentrations of bioelements in foliage and soil [27], and high intensity precipitation. In addition, on Okinawa Island, typhoons are frequent, which can cause serious salt stress in the vegetation particularly in events with low rainfall. Another factor is canopy disturbance by insect herbivory. Results from a litterfall study at the same site showed that the percentage of leaf area lost by insect herbivory has $20-35 \%$ and the annual mass of insect feces reached $0.87 \mathrm{Mg} \mathrm{ha}^{-1} \mathrm{y}^{-1}$ (Xu, pers. observ.). Therefore, the high apparent canopy leaching at our site may also be related to the frequent sea salt stress and insect herbivory.

\section{CONCLUSIONS}

The evergreen broad-leaved forest on Okinawa Island had low throughfall $(53.9 \%)$ and high stemflow (30.9\%) due to heavy rainfall, strong wind, and tree shape. The composition of rainwater at this site indicates that the subtropical forest has not been subjected to air pollution inputs. Rainwater was not acidic (mean $\mathrm{pH}=6.2$ ) and the $\mathrm{pH}$ decreased significantly as it moved through the forest canopy. Mean concentrations of bioelements were increased in throughfall and stemflow as rainfall passed through the canopy. Annual nutrient fluxes from net precipitation (throughfall + stemflow) are in the order: DOC > $\mathrm{Na}>\mathrm{K}>\mathrm{Ca}>$ total $\mathrm{N}>\mathrm{Mg}>\mathrm{P}$.

This research failed to determine a detailed $\mathrm{N}$ species because of limited resources, which limited us to make an intensive discussion about $\mathrm{N}$ behavior and cycling. In addition, as very little data are available for calculation of nutrient budgets, particularly $\mathrm{N}$ budget in Okinawa presently, there is an urgent need for more researches in this subtropical field with frequent typhoons. In order to better understand the effects of typhoon disturbance on $\mathrm{N}$ processes in this forest ecosystem, catchment studies (including $\mathrm{N}$-deposition, $\mathrm{N}$-mineralization, and hydrological response) with reliable data are necessary.

Acknowledgements: This study was made possible by partial support from the Japanese Ministry of Education, Sciences, Sports, and Culture. We are grateful to Drs. N. Yamamori, Y. Tokashiki and T. Enoki for invaluable suggestions; to Mrs. K. Baba, S. Miyagi, S. Oshiro, G. Kinjyo, and M. Asato, Subtropical Field Science Center of the University of the Ryukyus, for assistance in sample collection. Thanks also to Dr. L.A. Bruijnzeel for very helpful comments and correcting the manuscript.

\section{REFERENCES}

[1] Asbury C.E., McDowell W.H., Trinidad-Pizarro R., Berrios S., Solute deposition from cloud water to the canopy of a Puerto Rico Montane forest, Atmos. Environ. 28 (1994) 1773-1780.

[2] Barlett R.J., Ross D.S., Colorimetric determination of oxidizable carbon in acid soil solutions, Soil Sci. Soc. Am. J. 52 (1988) 11911192.

[3] Bernhard-Reversat F., Nutrients in throughfall and their quantitative importance in rain forest mineral cycling, in: Medina E., Golley F.B. (Eds.), Tropical ecological systems-trends in terrestrial and aquatic research, Springer Verlag, New York, 1975, pp. 153-159.
[4] Bruijnzeel L.A., Nutrient content of bulk precipitation in Southcentral Java, Indonesia, J. Trop. Ecol. 5 (1989) 187-202.

[5] Bruijnzeel L.A., Nutrient input output budgets of tropical forest ecosystems: A review, J. Trop. Ecol. 7 (1991) 1-24.

[6] Bruijnzeel L.A., Proctor J., Hydrology and biogeochemistry of tropical montane cloud forest: What do we really know? in: Hamilton L.S., Juvik J.O., Scatena F.N. (Eds.), Tropical montane cloud forests, Ecological Studies Vol. 110, Springer Verlag, New York, 1995, pp. 33-78.

[7] Cavelier J., Jaramillo M., Solis D., De Leon D., Water balance and nutrient inputs in bulk precipitation in a tropical montane cloud forest in Panama, J. Hydrol. 193 (1997) 83-96.

[8] Clark K.L., Nadkarni N.M., Schaefer D., Gholz H.L., Atmospheric deposition and net retention of ions by the canopy in a tropical montane forests, Monteverde, Costa Rica, J. Trop. Ecol. 14 (1998) 27-45.

[9] Crockford R.H., Richardson D.P., Partitioning of rainfall into throughfall, stemflow and interception: effect of forest type, ground cover and climate, Hydrol. Process. 14 (2000) 2903-2920.

[10] Crockford R.H., Richardson D.P., Sageman R., Chemistry of rainfall, throughfall and stemflow in a eucalypt forest and a pine plantation in south-eastern Australia, Hydrol. Process. 10 (1996) 1-42.

[11] Eaton J.S., Likens G.E., Bormann F.H., Throughfall and stemflow chemistry in a northern hardwood forest, J. Ecol. 61 (1973) 495508.

[12] Edwards P.J., Studies of mineral cycling in a montane rain forest in New Guinea. Rates of cycling in throughfall and litterfall, J. Ecol. 70 (1982) 807-827.

[13] Fujimoto K., Studies of elements originated from sea salt in stemflow and throughfall, Bull. Kochi Univ. For. 24 (1997) 147-185 (in Japanese with English abstract).

[14] Hafkenscheid R.L.L.J., Bruijnzeel L.A., De Jue R.A.M., Bink N.J., Water budgets of two upper montane rain forests of contrasting stature in the Blue Mountains, Jamaica, in: Gladwell J.S. (Ed.), Proceedings of the Second International Colloquium on Hydrology and Water Management in the Humid Tropics, Technical Documents in Hydrology No. 52, IHP-UNESCO, Paris and CATHALAC, Panama City, 2002, pp. 399-424.

[15] Hedin L.O., Armesto J.J., Johnson A.H., Patterns of nutrient loss from unpolluted, old-growth temperate forests: Evaluation of biogeochemical theory, Ecology 76 (1995) 493-509.

[16] Hokkaido Branch, Japanese Society of Analytical Chemistry (Ed.), Methods for water analysis, 4th ed., Kagakudojin, Kyoto, 1994, 493 p. (in Japanese).

[17] Hölscher D., Abreu Sá T.D., De Möller R.F., Denich M., Fölster H., Rainfall partitioning and related hydrochemical fluxes in a diverse and in a mono specific (Phenakospermum guyannense) secondary vegetation stand in eastern Amazonia, Oecologia 114 (1998) 251257.

[18] Iroumé A., Huber A., Comparison of interception losses in a broadleaved native forest and a Pseudotsuga menziesii (Douglas fir) plantation in the Andes Mountains of southern Chile, Hydrol. Process. 16 (2002) 2347-2361.

[19] Itô Y., Diversity of forest tree species in Yanbaru, the northern part of Okinawa Island, Plant Ecol. 133 (1997) 125-133.

[20] Iwatsubo G., Tokuchi N., Nakagawa Y., Rainfall and forest runoff chemistry: The 30-year change in the amount of dissolved elements in rainwater, input output budget of elements in rainfall and runoff water, and the extensive regional change of runoff water chemistry, Jpn. J. For. Environ. 39 (1997) 63-71 (in Japanese with English abstract).

[21] Jetten V.G., Interception of tropical rain forest: Performance of a canopy water balance model, Hydrol. Process. 10 (1996) 671-685.

[22] Koki Z., Studies on flying salt in Okinawa from the viewpoint of seashore conservation, Sci. Bull. Fac. Agric. Univ. Ryukyus 25 (1978) 429-554 (in Japanese with English abstract). 
[23] Kuraji K., Tanaka N., Shiraki K., Karakawa I., Ohta T., Effects of windspeed on stemflow volume in a mature Cryptomeria japonica and Chamaecyparis obtusa stand, J. Jpn. For. Soc. 79 (1997) 215221 (in Japanese with English abstract).

[24] Laclau J.P., Ranger J., Bouillet J.P., Nzila J.D., Deleporte P., Nutrient cycling in a clonal stand of Eucalyptus and an adjacent savanna ecosystem in Congo: 1 . Chemical composition of rainfall, throughfall and stemflow solutions, For. Ecol. Manage. 176 (2003) 105-119.

[25] Li L.H., The nutrient balance of the Castanopsis eyrei forest ecosystem in Wuyi mountain, China, Acta Phytoecologica Sinica 22 (1998) 263-271.

[26] Lin T.C., Hamburg S.P., King H.B., Hsia Y.J., Throughfall patterns in a subtropical rain forest of northeastern Taiwan, J. Environ. Qual. 29 (2000) 1186-1193.

[27] Liu W., Fox J.E.D., Xu Z.F., Nutrient budget of a montane evergreen broad-leaved forest at Ailao Mountain National Nature Reserve, Yunnan, southwest China, Hydrol. Process. 17 (2003) 1119-1134.

[28] Lloyd C.R., De Marqués F.A.O., Spatial variability of throughfall and stemflow measurements in Amazonian rain forest, Agric. For. Meteorol. 42 (1988) 63-73.

[29] Lovett G.M., Lindberg S.E., Dry deposition and canopy exchange in a mixed oak forest as determined by analysis of throughfall, J. Appl. Ecol. 21 (1984) 1013-1027.

[30] Marqués R., Ranger J., Nutrient dynamics in a chronosequence of Douglas-fir (Pseudotsuga menziesii Franco) stands on the Beaujolais Mounts (France). 1. Qualitative approach, For. Ecol. Manage. 91 (1997) 255-277.

[31] Miller H.G., Miller J.D., Cooper J.M., Transformations in rainwater chemistry on passing through forested ecosystems, in: Coughtrey P., Martin M., Unsworth M. (Eds.), Pollutant Transport and Fate in Ecosystem, Blackwell, Oxford, 1987, pp. 171-180.

[32] Moreno G., Gallardo J.F., Bussotti F., Canopy modification of atmospheric deposition in oligotrophic Quercus pyrenaica forests of an unpolluted region (central-western Spain), For. Ecol. Manage. 149 (2001) 47-60.

[33] Okita T., Murano K., Matsumoto M., Totsuka T., Determination of dry deposition velocities to forest canopy from measurements of throughfall, stemflow and the vertical distribution of aerosol and gaseous species, Environ. Sci. 2 (1993) 103-111.
[34] Oyarzun C.E., Godoy R., Sepulveda A., Water and nutrient fluxes in a cool temperate rainforest at the Cordillera de la Costa in southern Chile, Hydrol. Process. 12 (1998) 1067-1077.

[35] Parker G.G., Throughfall and stemflow in the forest nutrient cycling, Adv. Ecol. Res. 13 (1983) 57-133.

[36] Potter C.S., Ragsdale H.L., Swank W.T., Atmospheric deposition and foliar leaching in a regenerating southern Appalachian forest canopy, J. Ecol. 79 (1991) 97-115.

[37] Raich J.W., Throughfall and stemflow in mature and young wet tropical forest, Trop. Ecol. 24 (1983) 234-243.

[38] Ranger J., Gérard F., Lindemann M., Gelhaye D., Gelhaye L., Dynamics of litterfall in a chronosequence of Douglas-fir (Pseudotsuga menziesii Franco) in the Beaujolais mounts (France), Ann. For. Sci. 60 (2003) 475-488.

[39] Schroth G., Silva L.F., Wolf M.A., Teixeira W.G., Zech W., Distribution of throughfall and stemflow in multi-strata agroforestry, perennial monoculture, fallow and primary forest in central Amazonia, Brazil, Hydrol. Process. 13 (1999) 1423-1436.

[40] Soil Survey staff, Soil Taxonomy: A Basic System of Soil Classification for Making and Interpreting Soil Surveys, USDA Natural Resource Conservation Service Agriculture Handbook, U.S. Government Printing Office, Washington DC, 1999, 869 p.

[41] StatSoft, Japan Inc., Statistica User's Guide, 1999, 648 p. (in Japanese).

[42] Vitousek P.M., Sanford JR. R.L., Nutrient cycling in moist tropical forest, Ann. Rev. Ecol. Syst. 17 (1986) 137-167.

[43] Waterloo M.J., Schelleken J., Bruijnzeel L.A., Vugts H.F., Assenberg P.N., Rawaqa T.T., Chemistry of bulk precipitation in southwestern Viti Levu, Fiji, J. Trop. Ecol. 13 (1997) 427-447.

[44] Westman W.E., Inputs and cycling of mineral nutrients in a coastal subtropical eucalypt forest, J. Ecol. 66 (1978) 513-531.

[45] Xu X.N., Hirata E., Tokashiki Y., Shinohara T., Structure and species diversity of subtropical evergreen broad-leaved forest in northern Okinawa Island, Japan, J. For. Res. 6 (2001) 201-210.

[46] Xu X.N., Hirata E., Tokashiki Y., Enoki T., Shinohara T., Differences of soil properties between evergreen broad-leaved and pine forests in northern Okinawa Island, Japan, Jpn. J. For. Environ. 43 (2001) 1-8. 